\title{
TABUCCHI'S BRUTAL EMPIRES
}

Antonio Tabucchi, Italian novelist and scholar of Portuguese literature and culture, draws on countless images of Portuguese empire in his fictional writing, from different periods and in diverse geographical places. My focus in this article is the abrupt shift in Tabucchi's representation of Portuguese empire which takes place in the early ig9os. At this point, Tabucchi's Portuguese empire ceases to be a romanticized, Eurocentric space and becomes instead a brutal, violent world, characterized by repression and subjugation. I aim firstly to chart this shift, focusing on Tabucchi's I 984 novel Notturno indiano, his i99 I short story 'Notte, mare o distanza' (part of the collection L'angelo nero), and his I 997 text La testa perduta di Damasceno Monteiro. ${ }^{\mathrm{I}} \mathrm{I}$ then wish to locate this movement in the debates surrounding the imperial legacy which were taking place in Italy and Portugal in the early I990s, in order to examine whether Tabucchi's revisioning of empire may be contextualized against the reassessment of the Italian colonial experience at that time, and in particular against questions regarding whether the Italian empire was somehow truly different from other imperial models: an empire which was 'più mite, più umano, più tollerante, più costruttivo'. ${ }^{2}$

\section{The Absence of Italian Empire}

The imperial representations analysed in this article are drawn from the Portuguese empire, as Italian empire is all but absent from Tabucchi's writing. It appears fleetingly on two occasions: firstly in the 1975 novel Piazza d'Italia, and then in the ${ }_{198}$ I collection $I l$ gioco del rovescio. ${ }^{3}$ In both texts Africa is described in the barest terms. In Piazza d'Italia the characters Volturno and Quarto are sent to fight in (unnamed) African campaigns. In his letter home Quarto reiterates a common motif in depictions of Africa, writing that 'l'Africa è così grande che pare astratta e come una geometria immaginata' (Piazza, p. 29). Volturno meanwhile deserts the army to join a nomadic tribe, since 'aveva perso la testa per una mora velata e acre che acquetava i terrori nella libidine' (Piazza, p. 29). It may be significant that Quarto and Volturno are named after the starting and finishing points respectively of Garibaldi's expedition of the Mille in $\mathrm{s} 860 .^{4}$ The use of these names establishes a clear link between domestic and colonial projects, a theme which is central to Tabucchi's depiction of Portuguese empire, in which repression in the empire fosters violence and brutality at home. The only other possible evocation of Italian empire

${ }^{\mathrm{r}}$ References are to the following editions: Notturno indiano (Palermo: Sellerio, 200o); L'angelo nero (Milan: Feltrinelli, 2002); La testa perduta di Damasceno Monteiro (Milan: Feltrinelli, 2002).

${ }^{2}$ Angelo Del Boca and Nicola Labanca, L'impero africano nelle fotografie dell'Istituto Luce (Rome: Editori Riuniti, 2002), p. I 5. The text illustrates the ways in which such a myth was propagated by the images of empire produced and distributed by the Fascist Istituto Luce and stresses that such ideas persist to some extent even sixty years on.

3 References are to the following editions: Piazza d'Italia (Milan: Feltrinelli, I998); Il gioco del rovescio, 2nd edn (Milan: Feltrinelli, 200I). The second edition, containing three additional stories, was first published in 1989.

4 G. C. Abba, Da Quarto al Volturno: noterelle d'uno dei Mille ( 880 ; repr. Bologna: Zanichelli, I 92 I).

Modern Language Review, 102 (2007), 723-36

(C) Modern Humanities Research Association 2007 
occurs in the short story 'Paradiso Celeste', in Il gioco del rovescio. Characters in this story trade with an unnamed African country, which may be part of the former Italian empire, although it is never made clear whether this is the case. The (possible) mention of Italian Africa serves no real purpose in the story; indeed, the most significant element is that the exact nature of the business is unknown, since mystery and unanswered questions are central to the text.

While Italian empire is almost invisible in Tabucchi's writing, references to the Portuguese empire abound. The Azores, Madeira, India, Angola, and Mozambique appear in various texts, charged with differing degrees of importance. Although Tabucchi is not discussing the Italian empire, this does not exclude the possibility that his representations have a certain relevance to debates surrounding the Italian imperial legacy: in Tabucchi's writing depictions of Portugal (and Portuguese empire) may hold significance for Italian issues. The symbolic use of Portugal by Tabucchi has been overlooked by scholars, and Portuguese settings and characters are seen simply to reflect Tabucchi's love of the country, which he defines as 'il luogo dell'anima, il luogo dell'affetto [. . .]. Questa terra mi ha adottato e io l'ho adottata quasi trent'anni fa, accettandola come l'altra parte di me.' 5 Tabucchi is closely affiliated to the country, which he came to know through the works of the Modernist poet and writer Fernando Pessoa, having picked up a copy of Pessoa's poetry by chance when he was a student in Paris, choosing the text mainly because it was cheap. ${ }^{6}$ From such beginnings Tabucchi went on to become professor of Portuguese literature at the Universities of Pisa and Siena, worked for the Italian diplomatic service in Lisbon, and translated Pessoa's major work, O Livro do Desassossego por Bernardo Soares, into Italian. ${ }^{7}$ In r 99 I Tabucchi wrote his novel Requiem in Portuguese, entrusting the Italian translation to Sergio Vecchio. ${ }^{8}$ Scholars have focused on

5 P. Gaglianome and M. Cassini, Conversazione con Antonio Tabucchi: Dove va il romanzo? (Milan: Omicron, I997), p. 25. Tabucchi makes a similar claim in an interview with Antonio Borsari, defining Portugal as 'prima di tutto [. . . ] un'altra patria. Una patria sola mi sembra insufficiente' (Antonio Borsari, 'Cos'è una vita se non viene raccontata? Conversazione con Antonio Tabucchi', Italienisch: Zeitschrift für italienische Sprache und Literatur, I 3.2 [26] (November I 991), $2-23$ (p. 7)).

6 Tabucchi outlines this episode in Alberto Arbasino, Italo Calvino, Andrea Camilleri, Umberto Eco, Mario Luzi, Claudio Magris, Dacia Maraini, Antonio Tabucchi raccontano se stessi, ed. by Alberto Scarponi (Rome: Gangemi, 2002), pp. i 1 2-I 3. For a discussion of Tabucchi's relationship to Pessoa, see Joseph Francese, 'L'eteronomia di Antonio Tabucchi', Stanford Italian Review, I I ( I 990), I 23-38; Anna Botta, 'Mourning Modernism', Spunti e ricerche, i 2 ( 1 996-97), I 43-57; and chapter 4.3, 'Dialogue with the Past and the Self in Tabucchi', in Liz Wren-Owens, 'The Phoenix Speaks: The Reclamation of Socio-Political Engagement in the Works of Leonardo Sciascia and Antonio Tabucchi, I 975-2005' (unpublished doctoral dissertation, University of Warwick, 2006), pp. 2 I 9-49 (pp. 233-43).

7 Fernando Pessoa, Il libro dell'Inquietudine di Bernardo Soares, trans. by Maria José de Lancastre and Antonio Tabucchi, preface by Antonio Tabucchi (Milan: Feltrinelli, 2004). Tabucchi's critical writings on Pessoa are collected in Un baule pieno di gente: scritti su Fernando Pessoa (Milan: Feltrinelli, 2000).

8 Antonio Tabucchi, Requiem: un'allucinazione (Milan: Feltrinelli, I 992). The translation was entrusted to Sergio Vecchio since when Tabucchi tried to translate it himself, he found himself writing a different book, as he explains in Autobiografie altrui: poetiche a posteriori (Milan: Feltrinelli, 2003), pp. I I 2-42. Louise Sheehan suggests that Tabucchi's decision to write in Portuguese signifies a new level of absorption into Portuguese culture, in her article 'Tabucchi's Portugal', in Cross-Cultural Travel: Papers from the Royal Irish Academy Symposium on Literature and Travel, ed. by Jane Conroy (New York: Peter Lang, 2003), pp. 285-95 (p. 287). Joseph 
the process by which Tabucchi becomes more absorbed into Portuguese culture, choosing Portuguese characters, settings, and even the language, and have not considered whether the Portuguese setting permits Tabucchi to consider issues pertinent to Italian culture in other, significant ways. ${ }^{9}$

In my thesis I showed that it is only in texts set in Portugal that Tabucchi broaches questions of regional identity and the notion of a divided Europe, discussions which offer an important contribution to Italian debates in the light of the rise of the Lega Nord and of growing European integration. ${ }^{10}$ There I argued that Tabucchi's focus on Portugal does more than illustrate his love for the country, suggesting that his discussion of regional tensions in Portugal and his concern regarding Portugal's place in an increasingly unified Europe allow him to address issues pertinent to Italy. In the present article I wish to consider another value which may be afforded to Portuguese space, demonstrating that Tabucchi's changing depictions of Portuguese empire allow him to explore debates surrounding Italy's own imperial past, from a more distanced perspective.

\section{The First Wave of Portuguese Empire: 'Notturno indiano'}

R. A. H. Robinson divides Portuguese imperial history into three periods: the first empire, centred on Golden Goa and the east, which began to decline in the sixteenth century; the second empire in Brazil in the seventeenth and eighteenth centuries, which focused on slave trading with western Africa and which ended in 1820 with Brazilian independence; the third empire established in Africa, centred around Mozambique and Angola, which developed as part of the European 'scramble for Africa' in the late nineteenth century, lasting until the I970s. ${ }^{\text {II }}$ Tabucchi's first sustained depiction of Portuguese empire occurs in his 1984 novel Notturno indiano, which draws heavily on the imagery and themes of the first period of Portuguese empire.

Francese, on the other hand, suggests that the use of Portuguese permits a disarticulation of the writing self, bringing to the fore new aspects which are not part of the conscious ego (a theory Tabucchi discusses in his I 994 novel Sostiene Pereira, published by Feltrinelli): Joseph Francese, Narrating Postmodern Time and Space (New York: State University of New York Press, I997), pp. I38-39.

9 Arnould De Liederkerke notes that the character Damasceno Monteiro in La testa perduta di Damasceno Monteiro is named after a street where Tabucchi and his wife used to live, in his article 'Antonio Tabucchi le contrebandier', Magazine littéraire (July-August I997), I 54-59 (p. I 58). Louise Sheehan also traces the origins of character names and places in her article 'Tabucchi's Portugal', pp. 285-95. The importance of Portuguese food is analysed by Michela Meschini in her article 'Un'allucinazione gastronomica: i banchetti impossibili e inquieti di Antonio Tabucchi', in Soavi sapori della cultura italiana: atti del XIII congresso dell'A.I.P.I. Verona/Soave 27-29 agosto I998, ed. by Bart Van den Bossche and others (Florence: Cesati, 2000), pp. 397-403. Gian Paolo Biasin also considers the importance of Portuguese food in the section dedicated to Tabucchi in his Le periferie della letteratura: da Verga a Tabucchi (Ravenna: Longo, I997), pp. I 3 I-46.

ro Wren-Owens, 'The Phoenix Speaks', pp. i i 2-42.

${ }^{1}$ R. A. H. Robinson, Contemporary Portugal: A History (London: Allen and Unwin, I 979), p. 95. For an examination of Portugal's attempt to legitimize the 'third empire' in Africa following the Berlin Conference of I 884-85, see Eduardo de Sousa Ferreira, Portuguese Colonialism in Africa: The End of an Era (Paris: Unesco, 1 974), pp. 3 I-34. For a brief historical sketch of the Portuguese empire from its origins to decolonization, see also Bruno Da Ponte, The Last to Leave: Portuguese Colonialism in Africa (London: International Defence and Aid Fund, I974), pp. 7-ı. 
Notturno indiano recounts the adventures of an Italian character, Roux, as he travels across India in search of his missing Portuguese friend Xavier. Although the text is set in the present (I984), the India that Roux visits resounds with echoes of the sixteenth-century Portuguese empire. The protagonist travels from Bombay to Madras to Goa. ${ }^{12}$ These sites formed an important part of Portuguese India. Although Bombay later belonged to the British, from I 534 to I66 I the city formed part of the Portuguese empire. It was ceded to England as part of Princess Catherine of Braganza's dowry when she married Charles II of England. The final third of the text is set in Goa, which, as the site of the first Portuguese bishopric in India, was the stronghold of the Portuguese empire in India. The imperial links between Goa and Portugal are highlighted throughout the protagonist's time in the city, through both real and imaginary events. On a very simple level, Roux visits a hotel in the Vasco da Gama region of the city. This (otherwise unnecessary) mention of the area serves to underline the Portuguese imperial legacy, by evoking the name of a founder of the Portuguese Indian empire: Vasco da Gama was briefly Viceroy of India, but more importantly was the architect of the early military victories which made the empire possible. ${ }^{13}$ A more sustained and vivid encounter with Portuguese empire occurs at the Jesuit college in Goa. This religious space is an important legacy of empire, as the aims of Portuguese expansionism were both commercial and religious. Bruno Da Ponte stresses that 'for the first 300 years, the presence of Portuguese colonial rule was felt chiefly through trading posts, military posts and religious missions-conversion to Christianity went hand in hand with commerce and conquest' (Da Ponte, p. 6). Indeed, Vasco da Gama cited as his reason for going to India the wish to bring back 'Christians and spices' (Diffie and Winius, p. I $8 \mathrm{I}$ ), illustrating the way in which the desire to spread Christianity was as important an element of the colonial project as economic gain. Religion certainly represented a key plank of Portuguese imperialism. The most important Portuguese Jesuit was Father Francisco Xavier, and I would suggest that Roux's search for a character named Xavier has, in itself, significant imperial echoes. When Roux asks a doctor at the hospital in Bombay whether he has seen his friend Xavier, the doctor immediately focuses on the name and asks, 'come il missionario?' (Notturno, p. 23). Roux goes on to explain that 'credo che un suo antenato fosse di Goa, cosi almeno diceva lui', linking Xavier closely with the origins of Portuguese empire (Notturno, p. 23). It is in search of Xavier that Roux enters the Jesuit college in Goa, a space filled with mementoes of Portuguese empire, such as maps, books, and food. At the college Roux falls asleep and dreams that he encounters Afonso de Albuquerque, the first Portuguese viceroy to impose a civil administration on India, whom Diffie and Winius designate 'the most venerable and remarkable conquistador of them all' (Diffie and Winius, p. 244). In Roux's dream Afonso appears in his colonial dress:

portava un cappello triangolare di panno floscio, la barba lunga e grigia gli spazzolava

${ }^{12}$ The city is referred to as Bombay rather than Mumbai in the text, as was the convention at the time.

${ }_{13}$ See B. W. Diffie and G. D. Winius, Foundations of the Portuguese Empire I $4{ }^{1} 5^{-I} 5^{80}$ (Oxford: Oxford University Press, 1977), pp. I 75-86. 
il petto coperto da un corsetto trapunto di fili argentei. Le spalle erano avvolte da un mantello nero, ampio, di foggia antica, con le maniche a sbuffo [. . . . Portava degli stivali alti rimboccati alla coscia e una spada sul fianco. (Notturno, p. 76)

This dream underlines the way in which the protagonist's experience of India is closely tied to the India colonized by the Portuguese, and is firmly rooted in the sixteenth century.

The purpose of such evocations of Portuguese empire is, I would suggest, to underline the protagonist's isolation in the contemporary world, and to underscore his search for an other which will complement his fragmented being. ${ }^{14}$ As a European, he is already marked as 'other' from Indian culture, set apart from those he meets by his Eurocentric viewpoint and viewed as wholly European by Indians in the text. This occurs most tellingly in a conversation between Roux and a doctor at the hospital in Bombay. Roux asks whether the hospital has an archive, in which he may find records of Xavier's visit. The doctor looks at Roux with disdain, replying, 'questo è l'ospedale di Bombay [...] lasci da parte le sue categorie europee, sono un lusso superbo' (Notturno, p. 24). As Roux accompanies the doctor on his rounds, the doctor warns him: 'non tocchi niente [...] e non si avvicini troppo ai malati. Voi europei siete molto delicati' (Notturno, p. 28). The doctor, who trained in Zurich, is a cardiologist, although he admits that his is 'una specializzazione assurda, per l'India. Sono cardiologo, ma qui nessuno è malato di cuore, soltanto voi in Europa morite d'infarto' (Notturno, p. 3 I). Roux's separation from Indians is complete when he checks into the Taj Mahal, one of the luxury hotels which, as the doctor explains, monopolize all energy resources, even at the expense of the hospital. The Taj Mahal is the only place in Bombay where it is safe for Europeans to drink tap water, thanks to a water purification unit. As Roux observes, 'il Taj non è un albergo: con le sue ottocento camere è una città dentro una città' (Notturno, p. 34). In entering the Taj, Roux is separated from the India of Indians.

Roux is identified as European by all the Indians that he meets. By highlighting his division from the dominant European presence in the parts of India that he visits, Tabucchi makes Roux's isolation even more apparent. He is an Italian in a Portuguese space, even if that Portuguese presence is mainly historic. He does not belong to the contemporary Indian world, nor to the past European one, remaining a lone figure against backdrops which are 'other' to him. In Notturno indiano the depiction of Portuguese empire serves to strengthen the key theme of identity in the text, underscoring Roux's isolation and confirming a Jain prophet's analysis of Roux, in which he is told that 'tu sei un altro' (Notturno, p. 68). The text revolves around Roux's search for another element of his being, which may be embodied by Xavier or indeed may be represented by greater self-awareness. The only certainty is that Roux feels himself to be incomplete and dislocated, both internally and in relation to the external realities of past and present surrounding him.

Imperial space is only important, however, in what it signifies from a Euro-

${ }^{14}$ In her recent monograph Pia Schwarz Lausten asserts that this search for an other underpins all of Tabucchi's writings: L'uomo inquieto: identità e alterità nell'opera di Antonio Tabucchi (Copenhagen: Museum Tusculanum Press, 2005), pp. 49-72. 
pean perspective, and the implications of empire for the colonized are almost wholly omitted from the text's narrative. Notturno indiano does mention the poverty of India, but this is to some level romanticized, as in the case of the young prostitute who enjoyed a loving relationship with her client Xavier. Tabucchi's later texts dwell much more forcefully on the destructive, violent, and pernicious elements of Portuguese empire. Interestingly, as Tabucchi's representation of Portuguese empire shifts in significance, so too do the geographical locations of the empire he describes, and the colonial period itself. In focusing on the destructive nature of empire, Tabucchi moves from the sixteenth-century Portuguese colonies in India to the battles for decolonization in Angola and Mozambique leading up to 1975.

\section{The Third Wave of Empire: 'Notte, mare o distanza'}

'Notte, mare o distanza', part of the i99 I collection L'angelo nero, narrates a disturbing tale set in Portugal in I 969, in the immediate aftermath of Salazar's fall from power, and on the eve of the first democratic elections since the military coup of I 926. Although the text is set in mainland Portugal, the primary frame of reference is the struggle for decolonization in Angola and Mozambique, which began with armed revolt in Angola in i 96 I, following Portugal's refusal voluntarily to renounce imperial control in the aftermath of the Second World War. ${ }^{15}$ The text narrates an encounter between a government agent and a group of young people who have spent the evening reading poetry and discussing their hopes for the new democratic era. As they are walking home, the policeman drives up beside them and proceeds to insult and intimidate them for their political beliefs, stressing the need to give them 'una lezione politica'. Much of the text borders on the fantastic, such as when the memory of the narrator transforms the policeman's gun into a grouper fish. Yet the policeman's account of his time in Angola and Mozambique owes little to the fantastic or to the imaginary. Instead, his story, his 'lezione politica', is rooted in real brutality and violence. It is worth citing the policeman's account at length, as it offers a very different vision of the Portuguese empire from the benign representation of the imperial legacy in Notturno indiano. The policeman declares:

prima regola della lezione politica: amare il proprio paese. E per amare il proprio paese sapete cosa ci vuole? [. . . C Ci vuole l'odio. Odio per difendere la nostra civiltà e la nostra razza. E sapete come si riconosce una vera civiltà e una vera razza? Si riconosce se sa dominare un'altra razza. Ordunque, [ . . . per dominare un'altra razza bisogna in primo luogo dominarla sessualmente, e così ha fatto il sottoscritto, cittadino portoghese a tutti gli effetti, in servizio a Luanda e a Lourenço Marques negli anni di grazia I 964-ı 968. Così, miei cari stronzetti, con questo uccello. E mentre diceva questo si aprì i pantaloni e mostrò il sesso, lo agitò avanti e indietro e orinò contro la notte. E poi si chiuse i pantaloni e disse: con questo uccello ho difeso la nostra razza, stuprando le figlioline di quei figli di puttane del MPLA ${ }^{16}$ che tendevano imboscate ai nostri soldati eroici che avevano

${ }^{1}$ For an account of the independence movements in Angola, Mozambique, and Cape Verde and the subsequent Portuguese response, see Da Ponte, The Last to Leave, pp. 53-62; Ferreira, Portuguese Colonialism; Deirdre Meintel, Race, Culture and Portuguese Colonialism in Cabo Verde (Syracuse, NY: Maxwell School of Citizenship and Public Affairs, Syracuse University, I984), pp. 93-1 58; Robinson, Contemporary Portugal, pp. Io6-23.

${ }_{16}$ The MPLA was the Movimento Popular de Libertação de Angola, a nationalist movement 
lasciato i loro focolari per andare a difendere quei paesi di zulu dal comunismo. E le ho stuprate per bene, come si deve, e erano tutte di età indefinita, ma, potete credermi sulla parola, tutte inferiori ai tredici anni, perché a tredici anni le negre sono già donne fatte, io me ne intendo. E dopo che me le ero godute per benino, con questa mia amica pistola completavo il lavoro saggiando a quelle puttanelle il deretano, vale a dire che gli infilavo la canna nel culetto, e loro come si dimenevano, oh, se avete visto, e io, pum pum, due colpi, solo due, giusto per forargli gli intestini, e dopo quel trattamento intensivo avreste dovuto vedere i loro padri come diventevano loquaci, denunciavano perfino i fratelli, tutto dicevano dopo che le loro figlioline gli venivano restituite con due pallattole nel pancino, perché di figlie quegli attivisti ne avevano molte, eh sì, proprio tante, i negri fanno un sacco di figli, ma noi per fortuna abbiamo un sacco di pallottole. (L'angelo nero, p. 46)

The text examines the possibilities inherent in allowing one nation control over the other, and the potential abuse that empire entails. Tabucchi is perhaps discussing the metaphorical 'rape' of colonial cultures by imperial nations, although it is certainly possible that he is alluding to the violent tactics carried out by the Portuguese troops in Mozambique and Angola, particularly once the rebel forces began to gain ground. ${ }^{17}$ Whereas Notturno indiano focuses on a purely Eurocentric viewpoint, analysing the effect on an Italian of being caught between an Indian and a Portuguese space, 'Notte, mare o distanza' concentrates more on the methods through which one power gains control over another. Notturno indiano explores the relevance of imperial space for considerations of the self and otherness, yet in 'Notte, mare o distanza' empire becomes linked to violence, oppression, and brutality. Certainly, 'Notte, mare o distanza' does not permit any romanticized view of imperial rule.

\section{The Third Wave of Empire: 'La testa perduta di Damasceno Monteiro'}

Crucially, in 'Notte, mare o distanza' the violence of empire (or at least the violence of the fall of empire) is married to brutality and repression within Portugal itself. The very police officer who viciously abused girls in the Portuguese colonies also seeks to intimidate the Portuguese youths who will vote in the forthcoming elections. Hence Tabucchi presents the abuse of power as something that will transcend national boundaries once it has been allowed to flourish unchecked. Such a link between violence in the colonies and in the homeland is also stressed in Tabucchi's I 997 text La testa perduta di Damasceno Monteiro. The novel recounts the investigations of Firmino, a journalist, into the discovery of a corpse which has been decapitated and left in woods

founded in I 96 I, advocating direct action to end colonialism. The MPLA's counterpart in Guinea and Cape Verde was the PAIGC (Partido Africano da Independência da Guiné e Cabo Verde), founded in 9 $_{9} 6_{3}$, and in Mozambique it was FRELIMO (Frente de Libertação de Moçambique), founded in 1964 .

i7 The Portuguese were known to target villages believed to be helping guerrillas in order to gain leverage over the fighters themselves, concerned about loved ones. Da Ponte focuses on the Portuguese tendency to round up, harass, torture, and kill villagers, which was intended to intimidate as much as to punish those suspected of helping the guerrillas, and compares these tactics to the American strategies in Vietnam, where defoliants, napalm, and the destruction of villages were used as instruments of psychological warfare. Da Ponte does not address the question of whether sexual abuse of the type described by Tabucchi was commonplace, and Tabucchi may perhaps be using this torture as emblematic of wider abuses (Da Ponte, p. 59). 
outside Oporto, Portugal's second city. The journalist's research leads him to identify the corpse as that of Damasceno Monteiro, a young man who had worked at an import-export company. When Damasceno realized that the company was being used as a front for a drug-smuggling operation, he attempted to steal a heroin consignment in order to sell it himself. Midway through his theft, he was caught by the local drug baron and consequently tortured, killed, and decapitated. The local drug lord is Sergeant Titânio Silva of the National Guard, who, before joining the Portuguese police force, had served in the Portuguese army in Angola from I970 to I973, in the final years before Angola was decolonized in I975. That Silva was present in Angola in these years is important, as the period represents the moment when the Angolan guerrilla forces gained strength against the Portuguese army. Like the sinister police officer in 'Notte, mare o distanza', Silva claims to have acquired his national consciousness in Angola. In La testa perduta Silva asserts: 'diciamo che nei nostri territori d'oltremare ho acquisito la mia coscienza nazionale' (La testa perduta, p. I 89). At his trial for the murder of Damasceno Monteiro, when asked what he means by 'coscienza nazionale', Silva replies:

- Nel senso che stavo combattendo contro i sovversivi per la nostra civiltà.

- Con la parola civiltà a cosa si riferisce?

- A quella portoghese, perché la nostra è la civiltà portoghese.

- E con la parola sovversivi?

- Ai negri che ci sparavano addosso perché glielo dicevano quelli come Amílcar Cabral. ${ }^{18}$ Ho preso coscienza di difendere quei territori che sono stati nostri fin dai tempi dei tempi, quando in Angola non c'era cultura né cristianesimo: cose che abbiamo portato noi. (La testa perduta, p. I90)

When Silva is tried for the murder of Damasceno Monteiro, the defence team focuses on his heroic conduct in the African wars and his medal for bravery, suggesting that imperial heroism precludes violence in Portugal. Tabucchi's text as a whole takes a somewhat different view, closely linking colonial repression with brutality in the homeland.

Depictions of the brutality of the powerful when dealing with the powerless resonate throughout La testa perduta, and the violence perpetrated in the colonies perhaps functions as a cypher for wider abuses of power. Through the lawyer Mello Sequeiro (known as Loton throughout the text because of his resemblance to Charles Laughton), the protagonist Firmino comes to learn of the fate of many marginalized characters, who suffer abuse at the hands of respected figures. The text points to an absence of accountability when dealing with the powerless, as in the case of Angela, a prostitute taken to a house in Guimarães, 'dove c'era un giovanotto benestante che l'ha fatta legare da due scherani e le ha usate violenze fisiche, perché era uno sfizio che si voleva togliere, ma non

I8 Amilcar Cabral was a founding member of the PAIGC, the nationalist movement of Guinea and Cape Verde. Interestingly, he was one of the few assimilados, or 'assimilated citizens', who had similar rights to Portuguese citizens. The colonial authorities envisaged that, as an educated African, he would use his learning to bridge the gap between the Portuguese administration and Africans, rather than to foster resistance to colonial rule. Cabral was one of the intellectuals who founded the Centre for African Studies in the I 950s, which sought to engender a new consciousness of indigenous culture. Other key founders of the centre, such as Agostinho Neto and Mario de Andrade, also appeared at the head of political movements in later years. See Ferreira, Portuguese Colonialism, pp. 1 22-24. 
sapeva con chi farlo, così l'ha fatto con Angela, tanto lei è una puttana' (La testa perduta, p. I I I). The way in which Damasceno Monteiro's killers, the National Guard, are absolved of all responsibility for his death also seems to point to a situation in which the powerful may act with impunity. ${ }^{19}$ Tabucchi's concerns about the imperial past and about the actions of the powerful tie into wider unease about the rise of right-wing politics in Europe and the unaddressed remnants and legacy of Fascism in Europe. The waiter in La testa perduta is organizing a rally in support of gypsies in Portugal, who have been physically and verbally attacked in a new wave of racist intolerance. The way in which the gypsies have been targeted (and believed to have no recourse in the law) is in many respects reminiscent of the treatment of colonial subjects, as described by Silva and the policeman in 'Notte, mare o distanza'. The waiter belongs to an association called 'Diritti del Cittadino', which crucially seeks equality for all. This belief in citizenship is antithetical to the colonial notion of 'subjects', who have no rights. Tabucchi's disquiet regarding the rise of right-wing nationalism in Europe, and its attendant impact on minority groups, the marginalized, and a wider culture of intolerance emerges not only in La testa perduta and 'Notte, mare o distanza', but also in his r 994 novel Sostiene Pereira and his I 999 investigative reportage Gli zingari e il Rinascimento. ${ }^{20}$ Tabucchi's focus on the destructive and violent nature of empire in 'Notte, mare o distanza' and La testa perduta indicates a pressing need to examine the dangers of allowing an upper caste to dominate society without being held accountable to a legal framework which guarantees equality, citizenship, and justice for all.

Although these texts communicate the same message, they are very different in form. Critics have tended to divide Tabucchi's works into postmodern texts, which deal with notions such as ontology, epistemology, multiplicity, and selfreflexivity, and texts which deal with socio-political concerns such as justice and freedom. ${ }^{21}$ 'Notte, mare o distanza' (and indeed the whole collection of L'angelo nero) is considered to be a postmodern text, whereas La testa perduta is one of the texts often held up as an example of more 'engaged' writing (usually along with Sostiene Pereira). ${ }^{22}$ It is clear that the two texts approach the notion of imperial repression from different standpoints: in 'Notte, mare o distanza' the weapon of choice is a grouper fish, while Silva and his associates in La testa perduta employ very real tools to decapitate Damasceno Monteiro. Yet the texts seek to ask similar questions about imperialism and its pernicious impact both at

19 JoAnn Cannon discusses the text's reflections on torture and ethics in a wider sense in The Novel as Investigation: Leonardo Sciascia, Dacia Mariani and Antonio Tabucchi (Toronto: University of Toronto Press, 2006), pp. 87-100.

${ }^{\circ}$ Antonio Tabucchi, Gli zingari e il Rinascimento: vivere da Rom a Firenze (Milan: Feltrinelli, I 999).

2r Such a divide underpins Pia Schwarz Lausten's L'uomo inquieto and Flavia Brizio-Skov's Antonio Tabucchi: navigazioni in un arcipelago narrativo (Cosenza: Pellegrini, 2002), and is employed by Jennifer Burns in her chapter on Tabucchi in Fragments of 'impegno': Interpretations of Commitment in Contemporary Italian Narrative I980-200o (Leeds: Northern Universities Press, 200 I), pp. 6I-80, and by Cannon, The Novel as Investigation, pp. 73-100. A major contention in my thesis, 'The Phoenix Speaks', is that such a divide does not take into account the complexity of Tabucchi's fiction, and that the 'postmodern' texts offer a different, yet forceful engagement with socio-political concerns.

${ }^{22}$ Joseph Francese examines the difficult relationship between the 'real' and the text in L'angelo nero, in Narrating Postmodern Time and Space, pp. I38-54. 
home and abroad, which seems to suggest that the shift in Tabucchi's portrayal of empire is not occasioned by his move towards the more 'hardboiled' fiction of La testa perduta, but is part of a wider reconsideration of the significance of empire. $^{23}$

\section{The Changing Significance of Empire in Italy}

Tabucchi's representation of Portuguese empire clearly undergoes a significant shift in his writings. In 1984 the Portuguese empire appears in a rather romanticized way: a sixteenth-century concept whose legacy has more effect on Europeans than on the colonized. By the I 990 s empire increasingly signifies a violent, unaccountable force, with disturbing repercussions on the domestic scene. Patriotism and nationalism become intrinsically linked to repression and a refusal of democracy and of legitimate judicial procedures. I would suggest that such a dramatic change is linked to the reappraisal of colonialism which began to gather momentum in Italy during this period, as a growing focus on Italian atrocities during the colonial era problematized romanticized depictions of any empire.

Nicola Labanca identifies the r 990 s as a crucial moment in the reassessment of the Italian empire. He writes: "certo è solo in questi anni che è andata più diffondendosi la visione, già patrimonio della storiografia più critica, che il colonialismo italiano era "non diverso, non più umano, non più tollerante" degli altri, e che anzi in alcuni momenti si era macchiato di colpe pesanti'. ${ }^{24}$ Labanca charts the depiction of Italian colonialism from the end of empire until the beginning of the twenty-first century, illustrating the widespread reluctance to admit its brutal aspect (Oltremare, pp. 427-70). He suggests that the way in which those responsible for war crimes in the colonies went unpunished in the aftermath of the Second World War rendered any real debate regarding Italian colonialism impossible, especially since those who had been in positions of authority in the colonies continued to control access to state archives. Such a control of data is exemplified by the myths propagated by the state-sponsored series L'Italia in Africa, as Angelo Del Boca describes. ${ }^{25}$ The series was inaugurated in I952, by a decree of the Comitato per la documentazione dell'opera dell'Italia in Africa, fifteen of whose twenty-four members were ex-colonial governors or officials, while the vast majority of the other members were procolonial Africanists. More neutral historians were able to access the state-held archives only in the I970s, and still met considerable obstacles when compiling their research. ${ }^{26}$ More rigorous examinations of Italian colonialism began to appear from this period onwards, although they were accompanied by a wider refusal to question the myth of the 'Italiani brava gente'. Those who did manage to access the archives before the I970s, such as Angelo Del Boca, found

\footnotetext{
${ }^{2}$ Brizio-Skov sees La testa perduta as akin to Raymond Chandler's detective fiction: Navigazioni, pp. I $5 \mathrm{I}-53$.

${ }^{24}$ Oltremare: storia dell'espansione coloniale italiana (Bologna: Il Mulino, 2002), p. 457.

${ }^{25}$ L'Africa nella coscienza degli italiani: miti, memorie, sconfitte (Milan: Mondadori, 2002), pp. I I 4-I 5 .

${ }_{26}$ See Giorgio Rochat, 'The Italian Air Force in the Ethiopian War', in Italian Colonialism, ed. by Ruth Ben-Ghiat and Mia Fuller (New York: Palgrave, 2005), pp. 37-46 (p. 37).
} 
that their research findings met with derision. Del Boca recalls the response to his 1965 text La guerra d'Abissinia I935-I94I, and to his 1979 work Gli italiani in Africa Orientale, writing that 'per le mie denuncie del i 965 e i 979 mi presi spesso del bugiardo, dell'anti-italiano, del "nemico dell'esercito", (L'Africa nella coscienza degli italiani, pp. $120-2 \mathrm{I}) .{ }^{27}$ Labanca outlines the way in which the debate regarding the Italian view of the imperial legacy began to gather momentum during the late I 980 s and especially during the I990s, as critical historiography began to reach a wider public as well as the readers of specialized journals. Labanca views the 1992 republication of Del Boca's Gli italiani in Africa by the Oscar Mondadori series, allowing wide distribution and publicity, as 'un riconoscimento, se ce ne fosse bisogno, di come l'Italia degli anni Novanta non era più quella chiusa nella sua nostalgia colonialista' (Oltremare, p. 458). Public awareness of the Italian colonial legacy was reinforced by a number of political acts in this period, such as the revelation by General Domenico Corcione, Minister of Defence, that Fascist Italy broke the Geneva Convention and used gas to conquer Ethiopia; President Oscar Luigi Scalfaro's admission to the Ethiopian parliament that Italy committed grave crimes during the colonial period; and Massimo D’Alema's recognition that Italy had treated Libya badly during the Italian occupation (Labanca, Oltremare, p. 460 ). ${ }^{28}$

On a cultural level, this period is marked by the emergence of films and television programmes questioning the view of the Italian empire as benign. The year I 988 finally saw the Italian premiere of Mustapha Akkad's The Lion of the Desert, a film which had been made in 1979 , recounting the story of Umah al-Mukhtar, head of the resistance in the Libyan region of Cyrenaica, who was killed in the Soluch concentration camp in I93 I following a show trial. The Syrian-American director's film had been released worldwide in I980, except in Italy, where it was vetoed on the grounds that it damaged the honour of the Italian army. The Italian showing in I 988 was only at the Rimini film festival, which that year was devoted to colonial cinema. ${ }^{29}$ In 1986 , on the fiftieth anniversary of the Ethiopian war, a television programme investigating the Italian legacy, L'impero: un'avventura africana, was aired. The broadcast took place late at night, and so once again had a limited audience, yet like the

27 Angelo Del Boca, La guerra d'Abissinia I935-I94I (Milan: Feltrinelli, I965); Gli italiani in Africa Orientale: la conquista dell'impero (Rome: Laterza, I 979). Other early attempts to question Italian colonialism include Giorgio Rochat, Il colonialismo italiano (Turin: Loescher, I973), and Eric Salerno, Genocidio in Libia (Milan: Sugarco Edizioni, i 979).

${ }_{28}$ For an account of the Italian use of gas against Ethiopia, see Alberto Sbacchi, 'Poison Gas and Atrocities in the Italo-Ethiopian War', in Italian Colonialism, ed. by Ben-Ghiat and Fuller, pp. 4756. Nicola Labanca outlines the treatment of Libyans under the Italian occupation in 'Italian Colonial Internment', in the same volume, pp. 27-36. Ben-Ghiat and Fuller, in their introduction to the volume, indicate the ways in which Italy was actually one of the most aggressive colonial powers, since Italy was the first country to use military air power and air bombardments (during the Italo-Turkish War of I9I I-I2); the first country to use gases in violation of the 1925 Gas Protocol (in Libya and Eritrea in the I 920 s and Ethiopia in the I930s); the first country to wage a large-scale war after the First World War (the Ethiopian invasion); the first western country in the twentieth century to employ genocidal tactics outside the context of world war (in the Cyrenaica region of Libya) (Italian Colonialism, pp. I-I 2 (p. 4)).

29 See Angelo Del Boca, 'The Obligation of Italy towards Libya', in Italian Colonialism, ed. by Ben-Ghiat and Fuller, pp. I 95-202 (p. I 97), and Del Boca, L'Africa nella coscienza degli italiani, pp. $125-26$. 
showing of The Lion of the Desert it perhaps indicates another gradual step in the process of bringing the colonial legacy to the public eye. The myth of the 'Italiani brava gente' has by no means been quashed, and certainly still exerts a strong hold on the public imagination; indeed, Del Boca notes that eighty per cent of the letters written to the television station regarding L'impero: un'avventura africana expressed disbelief at the facts shown and anger at the dishonouring of Italy's reputation. ${ }^{3 \circ}$

Yet the beginning of the I990s, the precise moment when Tabucchi radically altered his depiction of empire, represents a key moment in the debate regarding the Italian colonial legacy: a moment when the brutal realities of imperialism come increasingly to the fore. It is worth signalling that this period is not only significant for the reassessment of the Italian colonial legacy, but also for a growing awareness of postcolonial issues in more general terms. Although the postcolonial debate is still underdeveloped in Italy compared with the situation in other European countries, the period did mark an increasing consciousness of such issues, through visible international debates such as discussion of Italy's legacy to Libya and the admission that Italy had in fact used nerve gas, and the introduction of new schoolbooks which did not focus solely on the glory of Italy's colonial past. ${ }^{31}$ As an outward-looking individual, Tabucchi would certainly have been aware of these trends, in relation both to Italy's own imperial past and to wider questions of postcoloniality in general. Tabucchi's journalistic writing, which discusses not only events (such as Italy's involvement in the war in Iraq) but also wider trends (such as changing attitudes to race and responses to global warming), indicates that he is aware of and reacts to contemporary debate. ${ }^{32}$ Although he does not directly address issues of (post)coloniality in his journalism, it seems reasonable to read the fictional texts discussed here as contributions to this debate, especially once discussions of Italy's imperial legacy entered the wider cultural spectrum though television programmes, readily available texts, and coverage of diplomatic debates regarding Italy's legacy to Libya.

\section{A Changing Significance of Empire in Portugal?}

If such a reassessment of empire in Tabucchi's writing is to be seen as relevant to the debate in Italy, then it is important to examine the contemporary view of empire in Portugal, as such a shift could be viewed as even more relevant to a debate in that context. There are interesting and significant parallels between the Italian perception of their colonies as run by 'brava gente' and the

$3^{\circ}$ Del Boca, L'Africa nella coscienza degli italiani, pp. ix-x. Labanca notes that the programme was made by freelance directors, Massimo Sani and Piero Berengo Gardin, which is perhaps significant in itself (Oltremare, pp. 465-66).

${ }^{3 \mathrm{I}}$ For a discussion of the depiction of empire in schoolbooks see Nicola Labanca, 'History and Memory of Italian Colonialism Today', in Italian Colonialism: Legacy and Memory, ed. by Jacqueline Andall and Derek Duncan (Bern: Peter Lang, 2005), pp. 29-46 (pp. 37-38), and Del Boca, L'Africa nella coscienza degli italiani, pp. i i6-i 7.

${ }^{32}$ For an analysis of Tabucchi's journalism from I 996 to I 999, see Brizio-Skov, Navigazioni, pp. 187-95, and for a wider discussion of the value Tabucchi attaches to journalism, both in his novels and in his newspaper articles, see chapter 5.I, 'The Value of Literature', in Wren-Owens, 'The Phoenix Speaks', pp. $25 \mathrm{I}-63$ (pp. 252-59). 
Portuguese belief that their empire was different from other colonies, since they had no official colour bar, and offered citizenship to Africans. As late as I960, the Overseas Minister Silva Cunha asserted that 'the form by which Portuguese colonialism began, the character it took from the beginning and maintained [. . .] defended us from the vices affecting the colonial projects of other peoples' (cited in Meintel, Race, Culture and Portuguese Colonialism, p. I03). These claims were based on the distinction between assimilados, who enjoyed all the rights of Portuguese citizens (even though these were limited by an authoritarian regime), and indigenas, who had no such rights. ${ }^{33}$ Theoretically, anyone over eighteen years of age could become assimilado by demonstrating fluency in spoken and written Portuguese, by having no police record, and by displaying a standard of living and lifestyle similar to that of Europeans. In reality, the states of assimilado and indigena 'amounted to institutionalized racism, a virtual color bar legitimized in the name of culture. Only Africans had to demonstrate worthiness for civilized status.' 34 'The inequalities inherent in the assimilado/indigena dichotomy are underscored by the fact that most Portuguese citizens living in the colonies would have had difficulty passing the tests (Ferreira, Portuguese Colonialism, pp. I I4-I 5). Although the Portuguese colonial administration claimed that their empire was different from the exploitative British and French models, their rule was governed by a belief in white supremacy. This is exemplified by the blunt statements made by General Kaùlza de Arriga, the military Commander-in-Chief in Mozambique until I 973, who declared that 'the blacks are not highly intelligent; on the contrary they are the least intelligent of all the peoples in the world' (cited in Da Ponte, The Last to Leave, p. 42).

Certainly, the Portuguese claims that they were benign colonizers were no more rooted in reality than the myth of 'Italiani brava gente'. The crucial difference lies in the recognition of the true status of such claims. The status of indigena was dropped by Portuguese colonial administrations in $196 \mathrm{r}$, following the armed revolts in Angola, perhaps as a tacit recognition of its inherent discrimination. ${ }^{35}$ More significantly, the coup d'état which toppled Prime Minister Marcello Caetano in the 'Revolution of the Flowers' in April I 974 was led by officers of the Portuguese army, themselves opposed to colonial wars that Portugal could not win. The officers were driven by a desire to start a new era, both within Portugal and in relations with the African countries that had been colonized, as is clear from their choice of who should lead Portugal

\footnotetext{
33 The Statute of 1954 defined the indigena as a person of Negro race who is governed by the customs of his own society and has not yet evolved to a cultural level or state of civilization which would permit him or her to be governed by the same laws as a Portuguese citizen. In ig6 i the Native Statute was repealed, and all inhabitants of the overseas territories were given access to citizenship without having to pay any fee or pass any test. However, in reality little changed. See Da Ponte, The Last to Leave, pp. 40-4I.

${ }^{4}$ Meintel, Race, Culture and Portuguese Colonialism, p. I 29. Meintel observes that while the state of indigena did not exist in the Cape Verde Archipelago, since the islanders were seen as intermediaries between the Portuguese and Africans, the badius (peasants from the island of Santiago) served as a symbolic counterpart to the indigenas, suffering many similar hardships, such as being subject to forced labour (ibid., pp. I 27, I 4 I-42).

35 Basil Davidson, 'Portuguese Colonial Values: An Introduction', in Ferreira, Portuguese Colonialism, pp. I $1-27$ (p. I 8 ).
} 
until a provisional government could be formed: General Spinola. The recently demoted Deputy Chief of Staff had written Portugal e o Futuro in I 974, in which he stated that a military solution to the colonial problem was not feasible, and that the local populations could not be won over through mere reforms within the existing colonial framework. ${ }^{36}$ Spinola was by no means a liberalhe had fought with Franco in the Spanish Civil War-but he was a pragmatist, and his views were shared by many in the emerging elite in Portugal: his book was tellingly published by Arcádia, a publishing house owned by CUF (Companhia União Fabril), the biggest economic group in Portugal. ${ }^{37}$ Thus, in the aftermath of the 1974 revolution a new consideration of the colonial era was permitted to emerge. Rather than as a colonial power, Portugal began to see itself as holding a special position between Africa and Europe, as a backward, but also European, country straddling the divide between the two continents (Robinson, Contemporary Portugal, pp. I94-22 I). The assessment of Portuguese colonialism as a destructive era emerged in the r970s, made possible by the surfacing of a new regime differentiated from the colonial past. Such a debate did not need to emerge many years later, as was the case in the Italian context, where any early claims of colonial repression and violence were met with derision.

\section{Some Conclusions}

The brutality of the battles for decolonization in Angola and Mozambique was no less visible in 1984, when Tabucchi wrote Notturno indiano, than in the I 990s, when he penned 'Notte, mare o distanza' and La testa perduta. The Portuguese perception of the imperial period also underwent little revision. The only difference between the assessments of empire in this period lies in the Italian perception and in Italians' willingness to challenge and question the myth of their benign empire. Tabucchi's representations of empire over this period are polar opposites: a romanticized view of it as belonging to the past, significant only for the colonizer, and a harsh representation of the brutalities and violence of empire as lived by the colonized. It would appear that Tabucchi's dramatic shift in the value with which he imbues imperial spaces must, in some way, contribute to the Italian perception of the colonial past. That he views it through the prism of Portugal does not make it any less significant, as the Portuguese setting seems one with which Tabucchi is comfortable, and the Portuguese filter offers both reader and writer a distance from events, a means through which to ask difficult questions of history. Through the lens of the Portuguese imperial past, reader and writer are able to tackle the issue of Italy's own brutal empire.

${ }^{36}$ A. De Spinola, Portugal e o Futuro (Lisbon: Arcádia, I 974).

37 See Da Ponte, The Last to Leave, p. 65. 